DOI: $10.17805 /$ trudy.2016.4.10

\title{
КРАСНАЯ АРМИЯ В ИРАНЕ: НЕИЗВЕСТНЫЕ СТРАНИЦЫ ВЕЛИКОЙ ОТЕЧЕСТВЕННОЙ ВОЙНЫ
}

\author{
А. Б. Оришев \\ (Российский государственный аграрный университет - \\ МСХА им. К. А. Тимирязева
}

Аннотация: В статье восстанавливаются события августа 1941 г., когда на территорию Ирана вступили части Красной Армии и войска Великобритании («Иранская операция»). В планах союзников было превращение Ирана в транзитную базу для поставок по ленд-лизу. Воинские части, введенные в страну, должны были обеспечить безопасность перевозок от подрывных действий немецккой разведки и прогерманских элементов.

Подготовлено на основе доклада автора на Всероссийской научной конференции «Военная история России», которая прошла в Московском гуманитарном университете 25 апреля 20162.

Ключевые слова: Красная Армия; Великая Отечественная война; Иранская операция; Иран; Великобритания; союзнические войска; Антигитлеровская коалиция

\section{RED ARMY IN IRAN: UNKNOWN PAGES OF THE GREAT PATRIOTIC WAR}

\author{
A. B. Orishev \\ (Russian State Agrarian University - MTAA)
}

\begin{abstract}
The article reconstructs the events of August 1941, when the Red Army and British troops jointly entered the territory of Iran. The Allies aimed to make Iran a transit base for supplies under Lend-Lease. The military units deployed in the country had to ensure the safety of traffic along the "Persian Corridor" against subversive activities of German intelligence and pro-German elements within. In history, these events have been known as the "Anglo-Soviet invasion of Iran".

This article is based on the paper presented at "The military history of Russia" conference, which was held at Moscow University for the Humanities on April 25, 2016.
\end{abstract}

Keywords: Red Army; Great Patriotic war; Anglo-Soviet invasion of Iran; United Kingdom; allied troops; anti-Nazi coalition 
Вводу войск в Иран предшествовала дипломатическая подготовка. Правительство СССР направило в адрес правителя Ирана Реза-шаха Пехлеви три ноты протеста. «Первая нота последовала 26 июня 1941 г., последняя - 16 августа, в которых практически в ультимативной форме СССР потребовал удалить с иранской территории членов германской колонии, проживавших в стране» (Оришев, 2002: 69). Естественно, что иранское правительство, заявившее о нейтралитете, посчитало для себя недопустимым уступать грубому нажиму. Сыграл роль и тот фактор, что в июне-августе 1941 г., когда Красная Армия отступала на всех фронтах, мало за рубежом кто верил, что СССР способен сопротивляться. Реза-шах Пехлеви не был исключением, поражение Советского Союза в войне с нацистской Германией было для него делом времени.

Дипломатическая переписка между Ираном и участниками Антигитлеровской коалиции закончилась тем, что 25 августа 1941 г. советский посол в Тегеране вместе со своим британским коллегой вручили премьерминистру Ирана ноту, в которой сообщалось о вводе войск (Akten zur deutschen ... 1961: 312).

Обратим внимание на юридическую сторону дела. СССР вводил войска в Иран, ссылаясь на статью 6 советско-иранского договора от 26 февраля 1921 г. Она позволяла проводить подобные операции. У правительства Великобритании подобной правовой базы для ввода войск не было. Следовательно, с позиций международного права только участие Великобритании в Иранской операции можно считать оккупацией независимого государства.

Сама Иранская операция началась ранним утром 25 августа 1941 г. «В северную часть Ирана со стороны Закавказья были введены 44-я и 47-я армии Закавказского фронта. 27 августа на иранскую территорию выдвинулись части 53-й Отдельной армии Среднеазиатского военного округа. Что касается британского союзника, то он бросил на Иран следующие части: 9-я танковая бригада, 21-я пехотная бригада, 5-я и 6-я дивизии. Объеденным силам союзников противостояли пять иранских дивизий: две на юге и три на севере» (Пограничные войска ..., 1995: 51).

Имеющиеся в российских архивах документы говорят о том, что серьезного сопротивления Красной Армии иранцы не оказали. Уже послевоенный период среди историков развернулась дискуссия по поводу того почему Реза-шах не смог или не захотел организовать оборону своей страны.

Факты же говорят о следующем: советские военные суда, подошедшие ранним утром 25 августа 1941 г. к иранскому берегу, подавили своим огнем береговую артиллерию. Повсеместно иранцы покидали свои позиции, офицеры и солдаты разбегались по домам. Так, за первые два часа Иранской операции были ликвидированы: 121 пост погранохраны, 
16 ротных гарнизонов, 8 резиденций пограничных комиссаров, 16 резиденций их помощников, 13 жандармских и полицейских управлений, 5 постов по охране железнодорожных и шоссейных мостов на реке Аракс (там же: 238).

Согласно донесениям командиров Красной Армии, иранцы избегали вступать в боестолкновения с красноармейцами. 25 августа они сдали без боя город Ардебиль, небольшое сопротивление было только оказано на перевалах Саин-Гядук и Балыхлы. «Вход танков в Ардебиль был настолько неожиданным, что некоторые официальные лица, в частности, жандармское управление работало нормально», - отмечалось в докладе о боевой деятельности 24-го танкового полка.

29 августа Красная Армия заняла города Урмию, Пехлеви, Решт. Подвозя стройматериалы и личный состав из Резайе, иранцы в течение нескольких дней укрепляли Кушинский перевал. Советские разведчики докладывали, что здесь для наступающих частей могут возникнуть серьезные проблемы. Однако при первом же боестолкновении с частями Красной Армии защищавшие перевал иранцы сдали позиции. Вспоминает бывший начальник штаба 53-й Отдельной среднеазиатской армии М.И. Казаков: «10-я горганская дивизия просто-напросто разбежалась, побросав оружие и снаряжение. Более организовано вела себя 9-я мешхедская» (Казаков, 1971: 72-73). Подобная картина наблюдалась повсеместно. «Обнаруженные 10 одномоторных иранских самолетов на аэродроме Тебриза не пытались завязать бой не только с советской боевой авиацией, но и с самолетами, летавшими в одиночку, что позволило командующему фронтом уже в первый день операции сделать вывод о слабости вооружения иранской армии», - говорилось в отчете о боевых действиях ВВС Закавказского фронта (Центральный архив Министерства обороны Российской Федерации - далее ЦАМО. Ф. 209. Оп. 1089. Д. 13. Л. 13).

«За весь период операции ВВС противника в воздухе противодействия не оказали и по аэродромам Закавказского фронта не действовали. В 6.20. 25 августа 1941 г. пять самолетов противника с большой высоты произвели бомбометание по мосту через реку Аракс у Джульфы. В 19.15 . 25 августа 1941 г. три самолета противника с высоты 2500 м произвели бомбометание по тому же мосту. В обоих случаях мост не пострадал», отмечалось в этом же документе (там же).

Сын Реза-шаха Пехлеви, наследный принц Мухаммед Реза в своих воспоминаниях дал оценку происходившим событиям: «Если не считать нескольких небольших столкновений, сопротивление иранской армии не дало никаких результатов. После того как закончился первый этап нападения, нашим войскам стало ясно, что сопротивление такому сильному противнику бесполезно» (Pahlavi, 1961: 70). 
На самом же деле у иранского командования были возможности для организации достойного сопротивления. Генералы армии Реза-шаха не смогли использовать особенности иранского ландшафта, который представлял серьезные трудности для продвижения вражеской армии. Например, театр военных действий отличала пересеченность местности горными хребтами, а это создавало большие проблемы для советской авиации. Резко снижал эффективность бомбометаний постоянно меняющийся рельеф местности. Наземные пункты были расположены редко, заметных сверху ориентиров практически не наблюдалось. Все это осложняло ориентировку и мешало вести разведку и бомбометание (Оришев, 2005: 71).

Иранские горы создавали препятствия для советской пехоты, части Красной Армии имели возможность передвигаться только по узким тропам. Для стороннего наблюдателя казалось странным, почему обороняющиеся не использовали этот фактор для организации засад. Серьезные проблемы для красноармейцев создали многочисленные реки и ручьи, разлившиеся после прошедшего на севере страны незадолго до 25 августа ливня. Непривычно высокая температура воздуха вынуждала бойцов Красной Армии периодически останавливаться, что приводило к заболеваниям гриппом и малярией. А это сказывалось на боеготовности советских войск.

Упомянем и такой факт, как невысокая боеспособность частей Красной Армии, вошедших в Иран. Они были недостаточно подготовлены, почти не знали театр военных действий, объекты противника, в штабах ощущался дефицит военных карт. Разведданные часто не соответствовали действительности, рекогносцировка местности была проведена поверхностно. В неудовлетворительном состоянии находилась телеграфная аппаратура. Приказы из штаба в части передавались с большим трудом, зачастую с опозданием. Неудовлетворительно была налажена работа тыла. Поэтому перебои с поставками на фронт продовольствия и питьевой воды являлись регулярными.

Также не было должного взаимодействия между отдельными частями Красной Армии, отсутствовала регулярная связь между сухопутными войсками и авиацией. Не все командиры умели эффективно использовать прикрепленные к ним авиачасти. В отчете о боевых действиях ВВС Закавказского фронта приводились конкретные недочеты в действиях советских летчиков: низкая дисциплина, неудовлетворительная ночная и штурманская подготовка, зазнайство и переоценка своих сил, неграмотная эксплуатация материальной части.

На неудовлетворительном уровне была организована служба снабжения действующих впереди частей. На переправе через реку Аракс было допущено большое скопление военной техники, что при налете иранской авиации могло бы привести не только к срыву переправы, но и к гибели личного состава. 
И, тем не менее, несмотря на перечисленные недостатки, Красная Армия триумфальным маршем прошла по территории северного Ирана. Соотношение потерь только при ликвидации иранских погранпостов приближалось 1 к 10. Это говорило о тотальном преимуществе Красной Армии над противником.

Особого внимания заслуживает вопрос о потерях. Если взять данные по 53-й Отдельной среднеазиатской армии, то они следующие: согласно архивным данным ее части захватили в плен 4150 иранских военнослужащих (из них 18 старших офицеров, 156 младших офицеров, 67 унтерофицеров и 3909 солдат) (ЦАМО. Ф. 447. Оп. 10181. Д. 11. Л. 28).

Заметим, что советское командование проявило гуманизм. Уже 9 сентября 1941 г. им было принято решение освободить из плена всех иранских солдат. Что же касается трофеев, то вооружение, снаряды, автомобили и прочее трофейное имущество красноармейцы вывезли на территорию СССР.

Говоря об общих итогах операции, следует обратить внимание на тот важный факт, что она была первой военной акцией в рамках действовавшей в 1930-е гг. военной доктрины - бить врага на его территории. В этом плане части Красной Армии приобрели в Иране неоценимый опыт наступательных действий на фронте шириной более 700 км, когда темп продвижения частей достигает 35-50 км в сутки. Был получен опыт по захвату городов танковыми частями путем окружения населенных пунктов с обоих флангов и внезапным выходом в тыл, в результате чего противник лишался возможности использовать фронтальную оборону.

Иранская операция показала, что для достижения поставленных целей нельзя пренебрегать войсками связи, необходимо оснащать их современными самолетами, автотранспортом, особое внимание уделять личному составу и набирать в эти войска грамотных и технически образованных бойцов.

Боевые действия в Иране также указали на необходимость четкого взаимодействия всех родов войск, показали, что успех наступательной операции зависит от умения начальников штабов координировать свои действия и слаженной работы тыла.

Как уже говорилось, уже в первые дни операции стало ясно, что союзники имеют безусловное превосходство над шахской армией. В сложившейся ситуации Реза-шаху ничего не оставалось, как удовлетворить требования союзников. В ноте от 1 сентября 1941 г. правительство Ирана приняло решение выслать из страны немцев и обещало впредь не допускать пребывания на своей территории германских подданных. Кроме того, оно дало согласие на транзит через свою территорию товаров и военного снаряжения в СССР и Великобританию. 
8 сентября 1941 г. между союзниками и Ираном было заключено соглашение, определившее дислокацию Красной Армии и английских войск на иранской территории. Согласно договоренности части Красной Армии расположились к северу от линии Ушну - Миандоаб - Зенджан -Казвин - Кередж - Хорремабад - Шахруд и в районе Мешхеда, а английские - к югу и западу от линии Ханакин - Керманшах - Рам -Бендер - Дилам. На остальной территории расположились шахские войска.

13 сентября 1941 г. началась высылка германских подданных из Ирана. В этот день была осуществлена высылка первой партии немцев, а 16 сентября - второй. По иранским официальным данным 397 германских подданных выехали из Ирана через Ахваз и 58 через Казвин (Архив внешней политики Российской Федерации - далее АВП РФ. Ф. 94. 1941. Оп. 26. П. 69а. Д. 31. Л. 85).

Следующим шагом стали важные решения по политическим преобразованиям в самом Иране. Основатель династии Пехлеви Реза-шах Пехлеви принял важное для себя и страны решение - он ушел в отставку. 15 сентября Реза-шах снял с себя полномочия главнокомандующего, а 16 сентября подписал акт отречения в пользу своего старшего сына Мухаммеда Реза. Истории было суждено, что 17 сентября в день падения режима Реза-шаха в иранскую столицу вступили части Красной Армии, а на следующий день - британские войска.

Таким образом, Иранская операция заняла достойное место в истории Великой Отечественной войны. Введение союзных войск в Иран укрепило советские и английские позиции на Среднем Востоке и обеспечило поставки в СССР военно-технической помощи. Одновременно потерпели крах планы Гитлера по подключению Ирана к блоку государств фашистской «оси». Бесценный опыт наступательных боевых действий получила Красная Армия, впервые добившаяся поставленной цели совместно с британским союзником. Итоги операции были важны и в моральнопсихологическом плане. Летом-осенью 1941 г., когда вермахт рвался к Москве, и решалась судьба советского государства, ее успешное завершение подняло боевой дух красноармейцев и вдохновило их на разгром главного врага - нацистской Германии.

\section{СПИСОК ЛИТЕРАТУРЫ}

Казаков, М. И. (1971) Над картой былых сражений. М. : Воениздат.

Оришев, А. Б. (2005) Иран, август 1941-го // Азия и Африка сегодня. № 7. С. $51-57$.

Оришев, А. Б. (2002) Гитлер вербовал себе союзников на Среднем Востоке. Тайное военное сотрудничество нацистской Германии, Ирана и Афганистана // Военно-исторический журнал. № 8. С. 68-71. 
Пограничные войска СССР в годы Второй мировой войны. 1939 - 1945 (1995). М. : Граница.

Akten zur deutschen auswärtigen Politik (ADAP) (1961). Ser. D. Bd. 13.1. Frankfurt am Main: Bernard \& Graafe.

Pahlavi Mohammad Reza Shah. Mission for my Country (1961). London : Hutchinson.

Дата поступления: 15.06.2016 г.

Оришев Александр Борисович - доктор исторических наук, доцент, заведующий кафедрой истории Российского государственного аграрного университета - МСХА им. К. А. Тимирязева. Адрес: 115533, Россия, г. Москва, Нагатинская набережная, д. 12, корпус 3, кв. 286. Тел.: + 7 (903) 00870-50. Эл. адрес: Orishev71@mail.ru

Orishev Alexandr Borisovich, Doctor of History, Associate professor and Chair, Department of History, Russian State Agrarian University - MTAA. Postal address: Apt.286, 12 Bldg. 3 Nagatinskaya Embankment, 115533 Moscow, Russian Federation. Tel.: + 7 (903)-008-70-50.E-mail: Orishev71@mail.ru 